\title{
Tinjauan Studi Literatur: Analisis Gambaran Pelaksanaan Sensus Harian Rawat Inap
}

\section{Literature Study: Analysis Of Implementation Of Census Inpatients}

\author{
Yulfa Yulia S.St., MKM ${ }^{1}$ \\ Oktamianiza, SKM, M.Kes ${ }^{2}$ \\ Ns. Deni Maisa Putra, S.Kep, M.Kep ${ }^{3}$ \\ Rahmadhani, S.SiT, M.Keb ${ }^{4}$ \\ Indah Oktavia $^{5}$
Jurusan Rekam Medis dan Informasi Kesehatan STIKES Dharma Landbouw Padang Dengan alamat jalan Jhoni Anwar No.29 Ulak Karang Padang
Email :yulfayuliayy@gmail.com

\begin{abstract}
The daily census is a way of knowing the number of patients entering, leaving, dying and moving between rooms. The purpose of this study was to describe the inputs (human resource, SOP, infrastructure) and processes (monitoring and evaluation) of the daily inpatient census using the literature study method. The research was carried out in a literature study by conducting a descriptive analysis by describing the facts, then analyzing it, looking for similarities, views, and summaries of several studies. The results of this study found that most $<50 \%$ of the daily census implementation was still experiencing delays. The delay in returning the census was caused by the lack of awareness of human resources on the importance of the data that had been collected for the benefit of the hospital. SOP have not been implemented optimally, the facilities and infrastructure to support census activities are inadequate. In addition, there is a lack of supervisory control over the implementation of census data filling activities. This will have an impact on the information that will be issued by the hospital regarding the health service activities that have been provided to patients. And besides that, the data that will be reported for various parties who need this data will be inaccurate.
\end{abstract}

Keywords: in patient census, human resource, SPO, monitoring.

\begin{abstract}
Abstrak
Sensus harian adalah suatu cara untuk mengetahui jumlah pasien yang masuk, keluar, meninggal dan perpindahan antar ruangan. Tujuan dari penelitian ini adalah untuk mendeskripsikan input (SDM, SOP, sarana prasarana) dan Proses (Monitoring evaluasi) terhadap pelaksanaan sensus harian rawat inap dengan metoda studi literatur. Pelaksanaan penelitian secara studi literatur dengan melakukan analisis deskriptif dengan mendeskripsikan fakta-fakta yang ada, kemudian di analisis, mencari kesamaan, pandangan, dan ringkasan terhadap beberapa penelitian. Hasil dari penelitian ini didapatkan bahwa sebagian besar $<50 \%$ pelaksanaan sensus hariannya masih banyak mengalami keterlambatan. Keterlambatan dalam pengembalian sensus disebabkan oleh karena kurangnya kesadaran SDM terhadap pentingnya data yang telah dikumpulkan bagi kepentingan rumah sakit. SOP belum telaksana dengan optimal, sarana dan prasarana pendukung kegiatan sensus tidak memadai. Disamping itu kurangnya pengawasan pimpinan terhadap pelaksanaan kegiatan pengisian data sensus. Hal
\end{abstract}


ini akan memberikan dampak terhadap informasi yang akan dikeluarkan oleh rumah sakit terkait aktivitas pelayanan kesehatan yang telah diberikan kepada pasien. Dan disamping itu data yang akan dilaporkan untuk berbagai pihak-pihak yang membutuhkan data tersebut menjadi tidak akurat.

Kata Kunci : Sensus harian rawat inap, SDM, SOP, Monitoring

\section{Pendahuluan}

Rumah sakit sebagai salah satu sarana pelayanan kesehatan merupakan tempat yang digunakan untuk menyelenggarakan upaya kesehatan dan memelihara, serta meningkatkan derajat kesehatan. Oleh karena itu rumah sakit harus mampu memberikan pelayanan yang baik kepada masyarakat pengguna jasa layanan kesehatan. Rumah sakit adalah institusi pelayanan kesehatan perorangan secara paripurna yang menyediakan pelayanan rawat inap, rawat jalan, dan gawat darurat (UU RI 44, 2009). Rekam medis adalah berkas yang berisi catatan dan dokumen antara lain identitas pasien, hasil pemeriksaan pengobatan yang telah diberikan, serta tindakan, serta tindakan dan pelayanan lain yang telah diberikan kepada pasien. Catatan merupakan tulisan - tulisan yang dilakukan kepada pasien dalam rangka pelayanan kesehatan Permenkes RI 269. (2008). Standar Pelayanan MinimalRumahSakit

Sensus harian yaitu kegiatan pencacahan/penghitungan pasien rawat inap yang dilakukan setiap hari pada suatu ruang rawat inap, dan berisi tentang mutasi keluar dan masuk pasien selama 24 jam mulai dari pukul $00.00 \mathrm{~s} / \mathrm{d} 24.00$ (Depkes RI, (2005), Petunjuk Pengisian, Pengolahan, Dan Penyajian Data Rumah Sakit,.Pengolahan sensus harian rawat inap dimulai dari pengisisan sensus harian rawat inap oleh kepala ruangan atau penanggung jawab dan sensus harian rawat inap dikirim ke ruang rekam medis setiap hari kerja jam 08.00 pagi. Setelah sensus harian pasien rawat inap diantaranya pasien masuk dan keluar pada hari yang sama, lama dirawat, jumlah pasien yang masih dirawat dan hari perawatan dan dilanjutkan dengan rekapitulasi pertriwulan rawat inap (DepKes RI, 2005).

Pelaporan rumah sakit merupakan suatu alat organisasi yang bertujuan untuk dapat menghasilkan laporan secara cepat, tepat, dan akurat.Rumah sakit secara garis besar mempunyai dua jenis pelaporan yaitu laporan internal dan laporan eksternal. Laporan eksternal adalah laporan yang ditujukan kepada direktorat jendral pelayanan medik, Dinas kesehatan provinsi, Dinas Kesehatan Kabupaten/Kota. Sedangkan laporan internal berasal dari statistic rumah sakit yang aktifitas pelaksanaannya dilakukan secara rutin bagi pasien rawat inapsalah satunya dengan menggunakan sensus harian (Depkes RI, 2006, Pedoman Prosedur Dan Penyelenggaraan Rekam Medis di RumahSakit di Indonesia.

Menurut penelitian (Yusuf, 2013) dengan judul Tinjauan pelaksanaan sensus harian rawat inap di rumah sakit umum daerah pandan arang boyolali didapati bahwa pembuatan sensus harian rawat inap berpedoman dengan petunjuk teknis pengisian sensus harian rawat inap, tetapi karena petunjuk teknis di setiap bangsal sudah tidak ada maka pembuatan sensus harian rawat inap sudah tidak perlu menggunakan petunjuk teknis tersebut. Perawat bangsal membuat sensus harian rawat inap tidak merasa kesulitan walaupun tidak menggunakan petunjuk teknis pembuatan sensus harian rawat inap, dikarenakan perawat bangsal telah terbiasa.Sensus harian rawat inap di buat satu lembar saat malam hari oleh perawat yang jaga malam. Batasan pasien masuk mulai pukul 00.01 hingga pukul 24.00, 
setelah lewat jam 24.00 WIB maka dihitung hari berikutnya. Sensus harian rawat inap dibuat berdasarkan buku laporan keperawatan yang ada pada ruang perawatan.

\section{Metode Penelitian}

Metode yang diperoleh dari 3 jurnal dan referensi yang ada kmudian dianalisa dengan metode deskriptif, Metode analisa deskriptif dilakukan untuk mendiskripkan fakta-fakta yang kemudian disusun dengan analisis, tidak sematamata menguraikan, namun memberikan pemahaman dan penjelasan secukupnya. Analisa data yang dilakukan dalam peneltian ini adalah dengan teknik literature review diantaranya mencari kesamaan (compare), cari ketidaksamaan (contrast), beri pandangan (critize), bandingkan (synthesize), dang ringkasan (summarize).

\section{Hasil Dan Pembahasan}

Peneliti melakukan studi literatur dan jurnal-jurnal yang terkait dengan penelitian yang akan diuraikan berdasarkan sumber referensi yang digunakan dalam penyusunan penelitian ini berasal dari jurnal-jurnal yang berkaitan dengan topik penelitian ini tentang Tinjauan Pelaksanaan Sensus Harian Rawat Inap.

Dari beberapa literatur yang ditelaah yaitu jurnal firman dkk (2017), Elise dkk (2015), Igustin dkk (2013). terdapat kesamaan mendasar terhadap pelaksanaan sensus harian rawat inap, dimana Kesamaan dilihat dari pelaksanaan sensus harian rawat inap yang masih mengalami keterlambatan dikarenakan jumlah SDM yang belum memadai, petugas kurang bertanggung jawab terhadap pengisian data sensus harian rawat inap, serta pelaksanaan sensus harian rawat inap belum sesuai dengan SOP yang ada sehingga berdampak ke pelaporan rumah sakit.
Dari jurnal Elise dkk (2015) ditemukan beberapa ketidaksamaan antara satu sama lain yang mana jurnal Elise dkk menggunakan dua SOP yaitu manual dan SIMRS sehingga menghasilkan data yang berbeda sedangkan jurnal Igustin dkk (2013), Firman dkk (2017) hanya menggunakan SOP manual. Dan terdapat juga perbedaan cara pembuatan sensus harian rawat inap belum sesuai dengan Depkes RI 2005 yang isinya sensus harian dibuat rangkap tiga.

Dari analisis dan telaah jurnal firman dkk (2017), Elise dkk (2015), Igustin dkk (2013). terlihat pelaksanaan sensus harian rawat inap masih belum sesuai dengan standar yang ditetapkan, hal ini terjadi karena SDM yang belum memadai, sarana prasarana yang tidak lengkap, SOP mengenai pelaksanaan sensus harian rawat inap tidak terlaksana bahkan ada beberapa rumah sakit tidak menggunakan SOP, proses monitoring evaluasi yang belum terjadwal dengan baik.

Dari analisis dan telaah jurnal firman dkk (2017), Elise dkk (2015), Igustin dkk (2013). ditemukan bahwa pelaksanaan sensus harian rawat inap terkendala disebabkan oleh kurangnya sarana prasarana pada pelaksanaan sensus harian rawat inap yaitu pelaksanaan dilakukan secara manual, tidak ada komputer, sehingga petugas harus mencatat manual kembali sensus harian ke lembaran sensus. Terlebih SOP belum terlaksana sepenuhnya sehingga mengakibatkan petugas tidak mengetahui berapa lama proses pengembalian sensus harian ke unit rekam medis. Sedangkan menurut penelitian lain faktor yang menghambat Pelaksanaan Sensus Harian Rawat Inap adalah SDM yang belum memadai, kurangnya petugas sensus harian rawat inap, namun beberapa upaya telah dilaksanakan oleh pihak rumah sakit yaitu dengan cara melibatkan beberapa petugas lain dalam proses pengantaran sensus harian ke unit rekam medis. 
Dari analisis dan telaah jurnal Firman dkk (2017), Elise dkk (2015), Igustin dkk (2013). ditemukan bahwa pelaksanaan sensus harian rawat inap masih mengalami keterlambatan. Hal ini dikarenakan beberapa faktor yaitu SDM yang belum memadai, tidak adanya sosialisasi terhadap petugas pencatatan sensus harian rawat inap dengan perawat bangsal, sarana prasarana yang masih minim, SOP yang mengatur mengenai sensus harian belum terlaksana, serta proses monitoring evaluasi terhadap sensus harian rawat inap masih belum terjadwal secara rutin. Hal inilah yang membuat sebagian besar proses pelaksanaan sensus harian rawat inap belum terlaksana dengan baik di rumah sakit.

\section{Kesimpulan Dan Saran}

\section{a. Kesimpulan}

Berdasarkan studi literature dari hasil penelitian dan pembahasan jurnal - jurnal diatas, dapat disimpulkan bahwa: Dari hasil analisa terhadap 3 jurnal ditemukan bahwa pelaksanaan sensus harian rawat inap masih mengalami keterlambatan. Hal ini dikarenakan beberapa faktor yaitu SDM yang belum memadai, tidak adanya sosialisasi terhadap petugas pencatatan sensus harian rawat inap dengan perawat bangsal, sarana prasarana yang masih minim, SOP yang mengatur mengenai sensus harian belum terlaksana, Hal inilah yang membuat sebagian besar proses pelaksanaan sensus harian rawat inap belum terlaksana dengan baik di rumah sakit.

Disamping itu proses monitoring evaluasi terhadap sensus harian rawat inap masih belum terjadwal secara rutin, Hal ini dikarenakan pada manajemen organisasi belum terlaksana dengan baik.

\section{b. Saran}

Sebaiknya penelitian ini lebih dikembangkan dengan kajian penelitian melihat data langsung ke rumah sakit tentang gambaran pelaksanaan sensus harian rawat inap karena permasalahan ini sangat krusial dan dibutuhkan rumah sakit sebagai bahan evaluasi dalam proses pelaksanaan sensus harian rawat inap serta dapat menjabarkan secara jelas frekuensi munculnya permasalahan tersebut di rumah sakit.

\section{Ucapan Terimakasih}

Pada kesempatan ini peneliti ingin mengucapkan terimakasih kepada Ketua Program Studi dan Ketua STIKES Dharma Landbouw yang telah banyak membantu sehingga peneliti dapat menyelesaikan penelitian ini dan pihak-pihak yang telah memberikan masukan dan bantuan kepada peneliti.

\section{DAFTAR PUSTAKA}

Budiyanti Yusuf Igustin, dkk,2013 Tinjauan Pelaksanaan Sensus Harian Rawat Inap Di RSUD Pandan Arang Boyolali Tahun 2013. https:// ejurnal.stikesmhk.ac.id/in dex.php/rm/article/viewFile/283 $\angle 257$

Bustami, 2011, Penjaminan Mutu PelayananKesehatan Dan Askep Tabilitasnya, Erlangga : Padang.file (pdf:///G;/JURNAL/3592-10537SM.pdf)

Cahya Diningrat Firman,dkk, 2015 Faktor-faktor keterlambatan PengembalianSensusHarian Rawat Inap Di RSUD KabCiamis https://jmiki.aptirmik.or.id/index .php/jmiki/article/view/84

Carpenter (2003). Langkah Analisis Data Penelitian Kualitatif.

Depkes RI, 2004, Ilmu Pengembangan dan Pemerdayaan SDM Kesehatan. (https://media.neliti.com) 
Depkes RI, (2005), Petunjuk Pengisian, Pengolahan, Dan Penyajian Data Rumah Sakit, Direktorat Jenderal Pelayanan Medic, Jakarta, Depkes RI.

Depkes RI, 2006, Pedoman Prosedur Dan Penyelenggaraan Rekam Medis di RumahSakit di Indonesia Revisi II, Direktorat Jenderal Bina Pelayanan Medik, Jakarta.

Garmelia Elise, dkk, 2018Tinjauan Pelaksanaan Kegiatan Sensus

Harian Rawat Inap Di RSUD Kota Salatiga http:// ejournal.poltekkessmg.ac.id/ojs/index.php/RMIK/a rticle/view/3592

Hatta, G. (2008). Pedoman Manajemen Informasi Kesehatan Disarana Pelayanan Kesehatan.

Hartono, B. (2010). Manajemen Pemasaraan Untuk Rumah Sakit. Jakarta

Kepmenkes RI no.37 (2007) standarprofesi-perekam-medis.pdf.

Kurniawan Agung, dkk, 2010 Analisis Pemanfaatan Data Sensus Harian Rawat Inap Untuk Pelaporan Indikator Pelayanan Rawat Inap Di RSUD Dr.Soeroto Ngawi https://ejurnal.stikesmhk.ac.id/in dex.php/rm/article/view/10

Moleong, Lexy J. (2013). Metode Penelitian Kualitatif.

Notoatmodjo Soekidjo, Metodologi Penelitian. Rineka Cipta

Permenkes RI 269. (2008). Standar Pelayanan MinimalRumahSakit (https://doi.org/10.1016/.cell.2009 .01.043)

Sudra Rano Indradi, (2010), Statik Rumah Sakit, Yogyakarta : Graham Ilmu

Sugiyono, 2014, Metode Penelitian Kuantitatif, Kualitatif, dan RED, Bandung :Alfabeta

Sudra Rano Indradi, 2010, Statik Rumah Sakit, Yogyakarta : Graham Ilmu (http:// perpustakaan.hafshawaty. ac.id//index.php?)

UU RI 44. (2009). Tentang Rumah Sakit.

STIKES Dharma Landbouw Padang. 2020. Pedoman Penulisan Karya Tulis Ilmiah, Padang :STIKES DL.

Yusuf, I. B. (2013). Tinjauan pelaksanaan sensus harian rawat inap di Rumah Sakit Umum Daerah PANDAN BOYOLALI. 